\title{
Article \\ Lurking Lions and Hidden Herds: Concealed Wisdom in the Hebrew Bible
}

\author{
Scott B. Noegel * and Corinna E. Nichols
}

check for updates

Citation: Noegel, Scott B., and Corinna E. Nichols. 2021. Lurking Lions and Hidden Herds: Concealed Wisdom in the Hebrew Bible.

Religions 12: 492. https://doi.org/ 10.3390/rel12070492

Academic Editor: Andrew E. Steinmann

Received: 21 May 2021

Accepted: 26 June 2021

Published: 30 June 2021

Publisher's Note: MDPI stays neutral with regard to jurisdictional claims in published maps and institutional affiliations.
Near Eastern Languages and Civilization, University of Washington, Seattle, WA 98195, USA; cor1nna@uw.edu

* Correspondence: snoegel@uw.edu

\begin{abstract}
This article presents evidence for a previously unrecognized literary device in the Book of Proverbs, in which texts that cluster references to animals also contain additional paronomastic allusions to animals. This device accords with the proverbs' instruction to search for hidden knowledge, and resonates with their emphasis on the study of wild animals as a source of divine wisdom. The device also appears in psalms and prophecies, where it generally entails references to domesticated animals; here, the function appears to be rhetorical or performative. These groupings of concealed allusions to animals also add to the growing number of examples of the textual device of clustering.
\end{abstract}

Keywords: allusion; animals; cluster; paronomasia; prophecy; proverbs; psalms; wisdom

\section{Introduction}

As has long been appreciated, the Book of Proverbs shows a profound interest in animal life. Mammals, birds, and insects of all kinds appear in numerous similes and metaphors and periodically occur as objects of study (Forti 2008, pp. 25-86). Indeed, the proverbs repeatedly teach that their behavior imparts wisdom if properly understood. With this in mind, we here present evidence for a hitherto-unrecognized literary device in Proverbs that involves paronomastic allusions to animals hidden in texts that cluster direct references to animals. ${ }^{1}$ These paronomastic allusions indirectly reference animals, and thus populate the text in suggestive ways. ${ }^{2}$ Our use of the term "cluster" builds upon the observations of Greenfield (1990), who used it to describe the poetic strategy found at Ugarit and Israel of culling from the repertoire of word pairs and associations to create new meaningful contexts. Since the strategy involves groupings or constellations of these devices, he referred to them as clusters. Since then, it has become clear that several other poetic features also occur in clusters, including the one examined here. ${ }^{3}$

\section{Discussion}

We divide our study into four sections. In the first, we provide evidence for the hidden animal device in Proverbs. In the second, we contextualize the device by examining the role that the animal kingdom plays in transmitting divine wisdom. In the third section, we offer additional examples of the device beyond Proverbs. In the conclusion, we discuss the import of our findings and suggest avenues for future research.

\subsection{Hidden Animal Life in Proverbs}

Prov 6:1-5

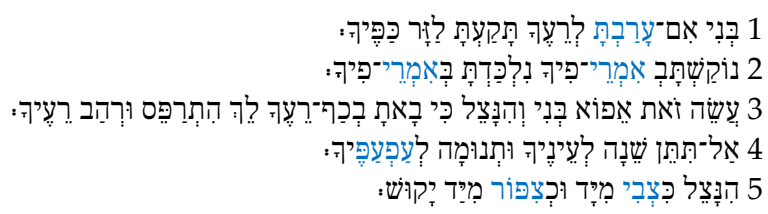

My son, if you have stood surety for your fellow, given your hand for another, 
You have been trapped by the words of your mouth, snared by the words of your mouth,

Do this, then, my son, to extricate yourself, for you have come into the power of your friend: go, prostrate yourself and press your fellow.

Do not give sleep to your eyes or slumber to your eyelids.

Deliver yourself like a gazelle from a hand or a bird from a snare.

Our first example applies the language of animal and bird trapping ${ }^{4}$ to the words of a man's mouth in order to teach that one should not offer to provide collateral for another person. The language of trapping is especially fitting since just prior, the verb for

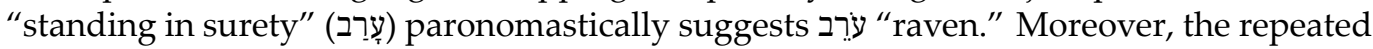

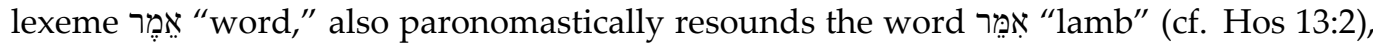
and both words are identical in the construct plural formation. The poet then refers to a צִִבְ "gazelle" "bird," in line 5, again in the context of trapping. The bird is paronomastically anticipated in the word "eyelids" (lit. "flutterers"), which resounds the word עוֹ עird." The language derived from hunting and trapping perhaps constitutes a clue to the reader/listener to be on the hunt for hidden creatures. ${ }^{5}$

Prov 19:11-13

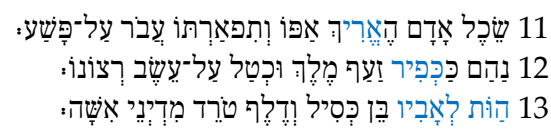

The intelligence of a man is his self-restraint. It is his glory when he passes over an offense.

A growl of a young lion is the rage of a king, but like dew upon the grass is his favor. ${ }^{6}$

A calamity to his father is a foolish son; like a leaky roof dripping constantly is the nagging of a wife.

In this example, the poet employs the hiphil form of the verb ארָָ to suggest the word

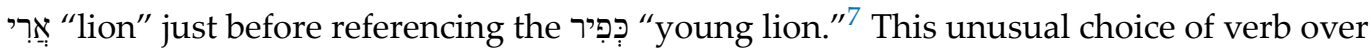
noun also draws attention to the lines. ${ }^{8}$ The usual idiom is a nominal construct formation:

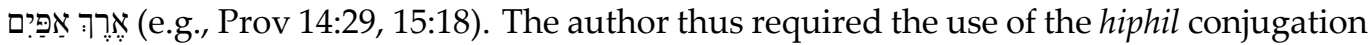

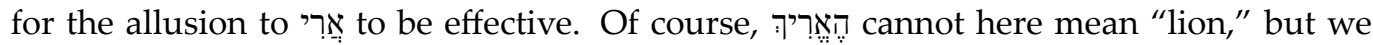

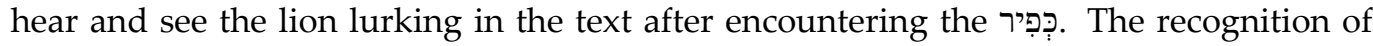
the hidden beast thus prepares us for line 13, in which the construct form "הָing "calamity"

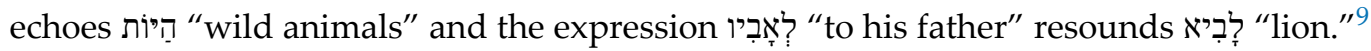
The finding of these concealed creatures puts into practice the directions given in Prov 1:6

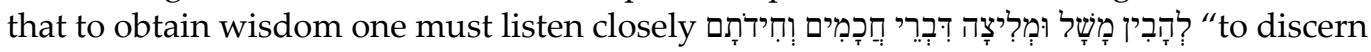
a proverb and its figure, the words of wise men and their riddles." From a literary perspective, the paronomasia contrasts self-restraint with rage and places the father in the role of the lion, who must restrain his urge to growl at his foolish son and contentious wife.

Prov 20:2-5

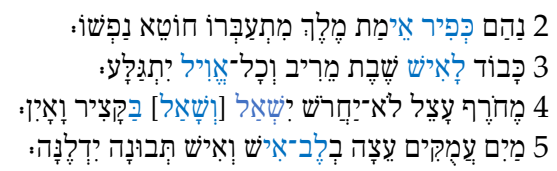

A growl like a young lion is the terror of a king. He who provokes his anger risks his life.

It is honorable for a man to cease from strife, but every fool quarrels.

In winter the lazy man does not plow, at harvest time he seeks and there is nothing. Deep waters are counsel in a man's mind, but a man of understanding draws them out. $^{10}$ 
Here, the teacher follows the reference to the כִּפִיר "young lion" with the expression

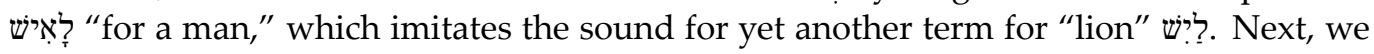

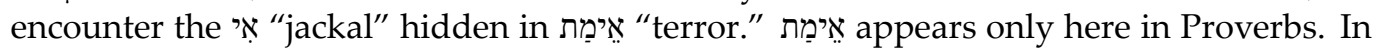
the next stich we find אֶיִ "איל "fool," which suggests," an animal that a lion might attack. "lion." The two allusive references to lions contrast the rage of a king with one who resists his anger. The fool is identified with the ram, and thus, with prey.

Prov 23:5

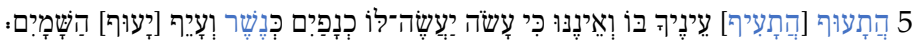

Your eyes blink at it (wealth), then it is no more. It surely makes wings for itself and like a raptor, it flies heavenward.

The נֶֶֶׁ "raptor" is here surrounded by verbs (both marked with Qere/Kethib) that

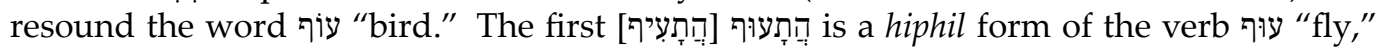

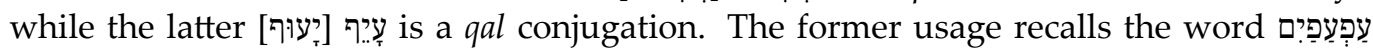
"eyelids," and suggests the meaning "in the blink of an eye."12

Prov 23:32-34

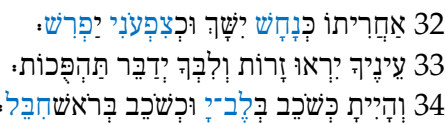

In the end it bites like a snake, it spits like a basilisk.

Your eyes will see strange things, and your heart will speak distorted things.

You will be like one lying in bed on high seas, like one lying on top of the mast.

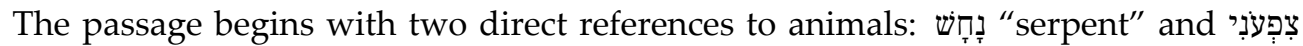

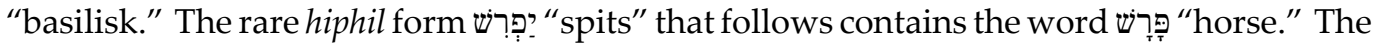
dangers that snakes pose for horses was well-known in the ancient world, as demonstrated

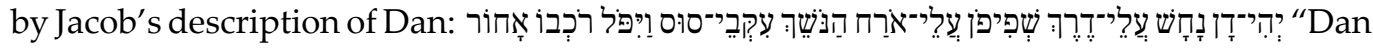
will be a snake by the roadside, a viper along the path, that bites the horse's heels so that its rider tumbles backward" (Gen 49:17). The fact that snakes and lions often co-occur in texts, suggests that we might also look for lions hidden in the text. ${ }^{13}$ We soon find one in

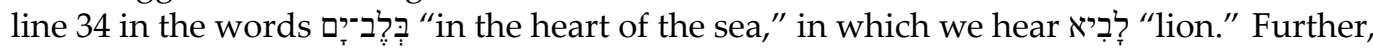

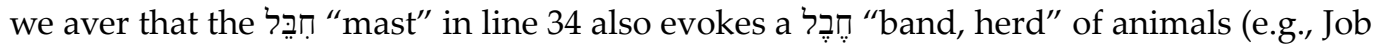
39:3). Finally, we note that the context involving snakes encourages us to hear in the word ראש "top" (lit. "head") the noun "venom."

Prov 26:12-13

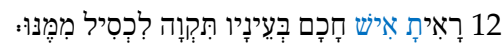

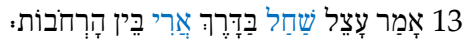

If you see a man who is wise in his own eyes, there is more hope for a fool than for him.

A lazy man says, "There's a lion cub on the road, a lion in the squares."

The second line in this passage contains two different words for lions: אִרִי The careful listener cannot help but hear in the words רִִ רִית "you see a man" (1. 12) an echo of the word תִ "he-goat," an animal that is potential prey for a lion. Abetting the

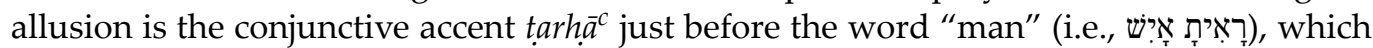
invites us to read the two words together. In essence, the lazy man who is wise in his own eyes cannot see that he is merely prey to predators about whom he chooses to do little other than pointing a finger. That the lion and he-goat are mutually associative is confirmed later in the book when the two are brought together again (Prov 30:29-31): 


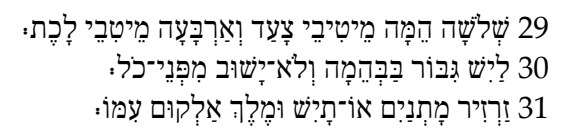

There are three that are stately of stride, four that carry themselves well:

The lion is mightiest among the beasts, and recoils before none.

The saluki, the he-goat, the king whom none dares resist.

Prov 28:1-2

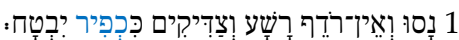

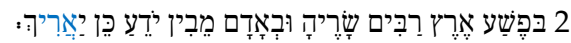

The wicked flee though no one gives chase, but the righteous are as confident as a young lion.

When there is rebellion in the land, many are its rulers, but with a man who has understanding and knowledge, stability will last.

Here, again, we encounter the כִִִּּּ "young lion," which naturally evokes its word pair אָרִ This time we find it in the following hiphil form of the verb Thus, unlike Prov 19:11-13, where the allusion precedes the animal, the direct reference to the כִכִִִּ alerts the reader to be on the lookout for hidden beasts. In addition, the literary context is also different. In this passage, the righteous is both the confident lion who does not flee, and the one who remains steadfast in a time of rebellion.

Prov 28:13-14

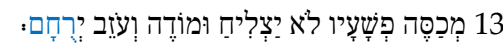

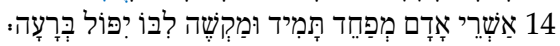

He who covers up his transgressions will not prosper, but he who confesses and abandons (them) will find mercy.

Happy is the man fearing constantly, but he who hardens his heart will fall into evil.

In this passage, the poet encourages us to find a רֶ "vulture" in the verb ירִֶ "find mercy," by following it with paronomasia on the language of bird trapping, first in "fearing," which contains חפ "a trapping net for birds" (cf. Prov 7:23), and "hardens," which suggests משוֹ "bait of a fowler" (cf. Prov 18:7, 20:25). ${ }^{15}$ As Jeremiah famously

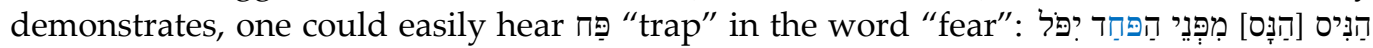
"he who flees from the terror will fall into the pit, and he who climbs out of the pit will be caught in the trap" (48:44)

Prov 28:15-16

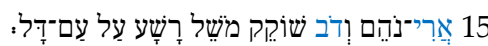

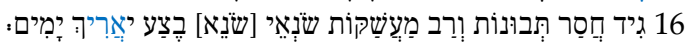
people.

A growling lion and an attacking bear is a wicked man who rules over a helpless

A prince who lacks discernment is very oppressive. He who hates unlawful gain will live long.

This passage couples the "אִרִ "lion" and "bear" in line 15, and follows them with

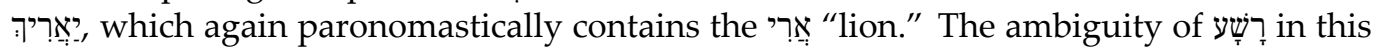
sentence gives one pause when reading. As it is, it can be a substantive "wicked man" or adjective "wicked." If it is an adjective, it modifies the participle משֶ "ruling," permitting the translation above "a wicked man who rules." However, if it is a substantive, we must read משֶ as another participle meaning "be like, resemble" (here with a plural antecedentnot unknown, cf. Gen 27:29, Num 24:9, Isa 3:12, Mic 1:9, Prov 3:18), and render "A growling lion and an attacking bear resemble a wicked man ... " The amphiboly here forces one to 
ponder whether the teacher has created a simile or metaphor, and to consider the polysemy of משי ${ }^{16}$ The reading "ruling," is confirmed by the parallelism of the next line that begins with "מָגיר "prince." The literary context here creates a contrast between the wicked ruler as a vicious lion, and the one who rejects unlawful gain and receives long life. The lion concealed in יָּרִיך creates a chiasm with the previous verse, thus heightening the contrast.

Prov 30:13-19

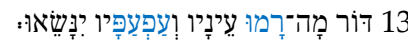

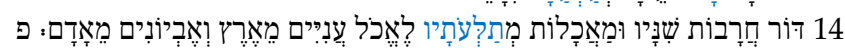

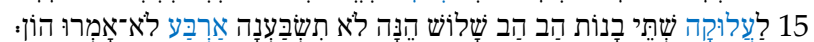

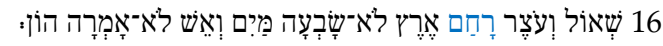

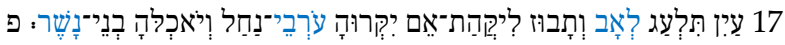

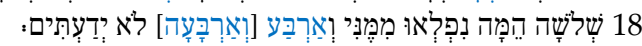

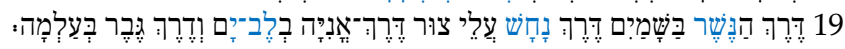

There is a generation that lifts its eyes and lifts up its eyelids.

There is a generation whose teeth are swords and whose molars are knives to eat the poor from the earth and the needy from the mankind.

The leech has two daughters: "Give!" and "Give!" There are three things that are never satisfied, four that never say, "Enough!"

Sheol, the (barren) womb, land that is not satisfied for water, and fire does not say, "Enough!"

The eye that mocks a father and scorns obedience to mother: the ravens of the wadi will peck it out and the young vultures will eat it.

Three things there are too wonderful for me, four that I do not know them:

The way of a raptor in the sky, the way of a snake on a rock, the way of a ship on the heart of the sea, and the way of a man with a woman.

Our final demonstration of the device is particularly artful. ${ }^{17}$ In this pericope, the poet

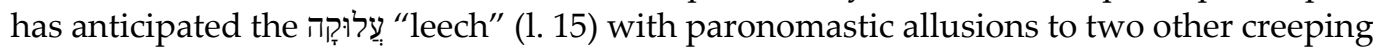

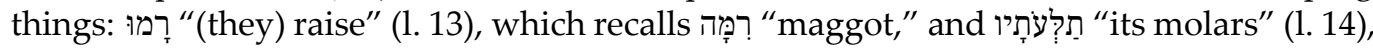

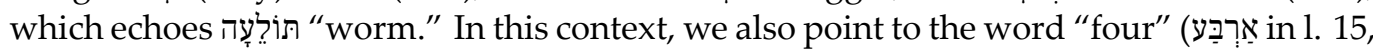

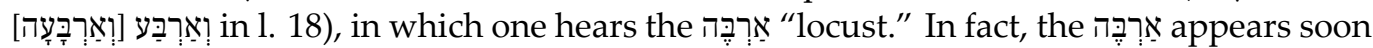
afterward in line 27 as one of the smallest, but wisest creatures. The poet then anticipates

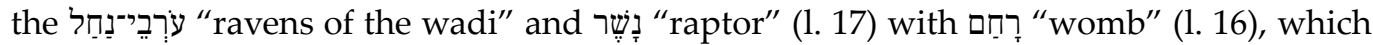
evokes לִ ְָָב "a father" (with preposition), which again suggests לְבְיָ "lion." Then, in line 19, the poet brings together the "raptor" and the "snake," which invites us to look for a lion. We find it once again in the expression בְלֶביָָ "in the heart of the sea," which paronomasti-

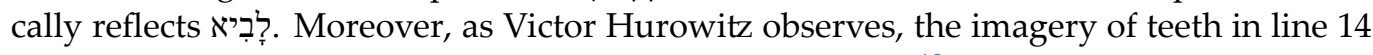

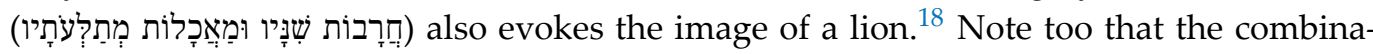
tion of creeping things and birds is anticipated in line 13, which follows the allusion to the

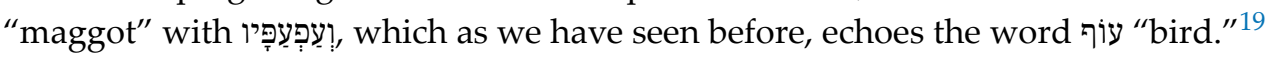

\subsection{The Animal Kingdom as Transmitters of Divine Wisdom}

Numerous biblical passages identify animals as numinous creatures and sources for obtaining divine wisdom. ${ }^{20}$ Proverbs is particularly clear on this. Thus, it advises the lazy: "Go to the ant, sluggard, and look at its ways, and be wise (חְָָכ)" (Prov 6:6). Proverbs also

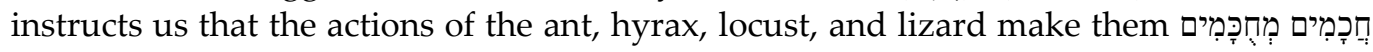
"wisest among the wise" (Prov 30:24). Wild creatures whose behavior signaled changes in season were deemed especially wise, as Jeremiah prophesies (Riede 2002, pp. 1-28):

Yea, the stork in the sky knows its appointed time,

And the turtle-dove and the golden oriole obey the time of their coming,

But my people do not know the rule of Yahweh. 
How can you say, "We are wise (חָכָדָמים) and the law of Yahweh is with us?" (Jer 8:7-8). ${ }^{21}$

See also Job's words to his friends:

Ask the beasts, and they will teach you, and the birds of the air, and they will tell you ... or speak to the fish of the sea, and they will inform you. Who does not know among these that the hand of Yahweh has done this? (Job 12:7-9)

The author of Kings considered it important enough to include the knowledge of all animals, birds, and fish as constituting a portion of Solomon's wisdom (1 Kgs 5:12-13). According to Othmar Keel and Silvia Schroer: "Observation of animals offered people the possibility of becoming wise, of coming closer to the divine order (of nature) and thus to God himself" (Keel and Schroer 2015, p. 50). Thus, when Yahweh asks Job from the whirlwind "who put wisdom in the ibis and gave the wild rooster understanding?" (Job 38:36), the implicit answer is that he did..$^{22}$

We find it meaningful that many of the concealed creatures are lions. Given the close association generally in the ancient Near East of lions with royal power, ${ }^{23}$ one must consider the possibility that, as a manual of statecraft, Proverbs teaches that one should always be on the lookout for kings, whose actions and informants may sometimes be furtive.

We also observe that all of the cases of hidden beasts that we have examined involve wild animals, not domesticated. This is because, throughout the Near East generally, wild animals were understood as numinous creatures that stood between God and humans. Consequently, biblical texts depict wild beasts as divine agents, portray them as numinous beings that humans cannot control without divine assistance, and contain similes and metaphors that depict Yahweh as a wild animal, and never as a domesticated one. ${ }^{24}$

We contend that the belief in wild animals as sources of divine wisdom, coupled with the poetic strategy of proverbs generally to conceal wisdom in its turns of phrase, paronomasia, and polysemy, offers a context for understanding the device. The discovery of hidden animals is essentially a discovery of sources of divine wisdom. With each reveal, one must consider the behavior of these animals and the insights that it imparts to the text. In many ways, the device functions like some Hebrew acrostics that employ the name of the consonant or a paronomastic reflection of it in the line to which it belongs, thus offering clues to the letters of the acrostic. ${ }^{25}$

\subsection{Hidden Animals beyond Proverbs}

The presence of this device in Proverbs naturally encourages one to look elsewhere in the Bible for additional cases. We opine that one should be especially encouraged to do so in texts that cluster direct references to animals. We offer below a few candidates in full recognition that it is likely, if not probable, that future researchers will discover additional examples.

Psalm 22:17

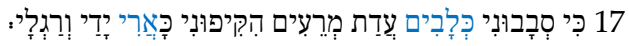

Dogs surround me. A pack of evil ones encircle me like lions (they attack) my hands and feet.

The psalmist compares evil people who surround him to both dogs and lions. After hearing the word "lion," the astute hearer is forced to rethink "dְְְָבִים "dogs" as the phrase

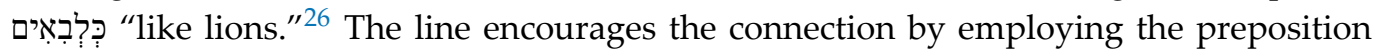

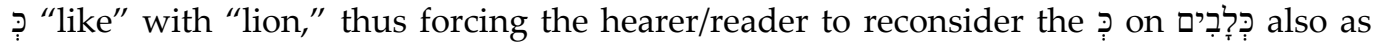
the preposition - another device of repetition and variation involving prepositions found elsewhere in the Hebrew Bible (See Noegel 2021, pp. 303-5). The paronomasia forces one to consider that the "dogs" who surround the poet are really "lions," and thus greater threats than they first seemed. ${ }^{27}$ 
Psalm 49:13

Man does not abide in honor. He is like the beasts that perish.

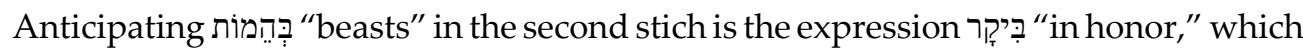
suggests by dint of sound בָָָָר "cattle, herd." "28 Complicating the passage is a clever case of polysemy. The niphal form נְְִִ can mean "he is like" or "he will be ruled." Thus, we may render the second half of the verse also as "he will be ruled like the beasts that perish." The paronomastic allusion to "cattle, herd," thus embodies the line's content by identifying the passing "honor" of humankind with the beasts to which he is likened. As if to draw attention to the line's devices, the psalmist repeats the verse with some interesting changes as the concluding line of the poem $(49: 21) .^{29}$

Psalm 49:15

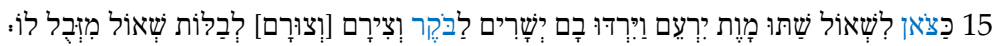

Like flocks to Sheol they appoint Death, who shepherds them. The upright will rule over them in the morning, and their image will waste away in Sheol (far) from his (Yahweh's) lofty abode.

The same Psalm again employs the device in line 15, this time with variation. The passage starts with reference to צ' "flocks," and personifies Sheol and Death as "רְי:" "(the one who) shepherds them," and shortly afterwards employs the noun בְּק "morning," which similarly evokes בָָָ "cattle, herd." 30 The verse refers to those who place their confidence in wealth. As in Ps 49:13, the psalmist connects their fate with those of beasts.

Psalm 50:9-11

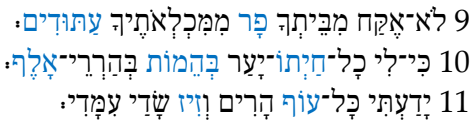

I claim no bull from your estate, no he-goats from your pens.

For mine is every animal of the forest, the beasts on a thousand mountains.

I know every bird of the mountain, and the creatures of the field are subject to me.

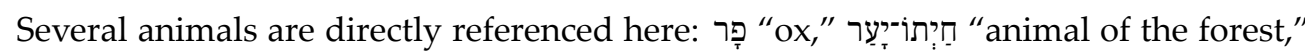

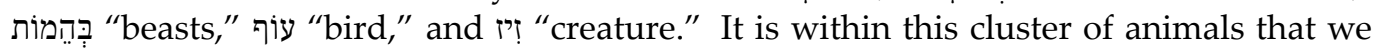
find אָָלֶ, which here means "thousand," but also recalls "cattle," especially following

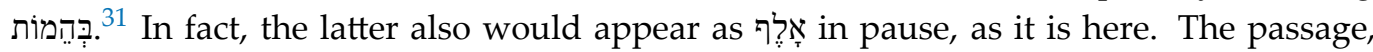
which appears to quote Yahweh, separates the domesticated animals of sacrifice from the animals in the wild. The former belong to Israel, the latter to Yahweh. The phrase "a thousand mountains," offers a bridge between the two, and puts form into function, as one must here distinguish between the "thousand mountains" that provide habitat for Yahweh's wild creatures and domesticated "cattle."

Psalm 65:14

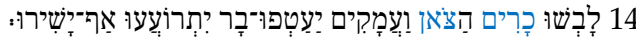

The meadows are clothed with the flocks, the valleys mantled with grain. They raise a shout; indeed, they sing.

The psalmist here personifies the meadows and valleys as praising Yahweh. Pre-

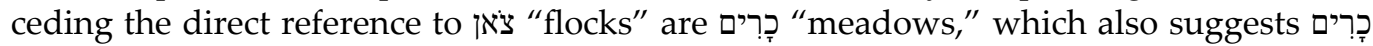
"rams," a fitting allusion given the presence of herds. As the final verse of the Psalm, it 
combines the promise of fertile crops and herds that embodies Yahweh's response to the faithful.

Psalm 78:27

27

He rained upon them meat like dust, and like the sand of the seas, winged birds.

This Psalm recounts the divine arrival of quails in the desert. We suggest that here the expression חוֹל יַיפימים "sand of the seas," also suggests "Phoenix of days." This bird has

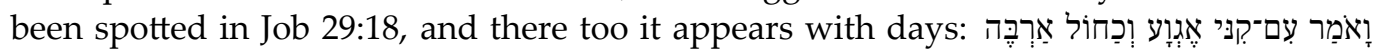
יָמִים "And I said, I will perish with my nest, but like the Phoenix I will multiply days" (See Dahood 1974, pp. 85-88). The allusion would be even more clear in the pre-Masoretic text. ${ }^{32}$ The Psalmist employs the polysemy here to register both the abundance of quails and their role in preserving the Israelites' lives in the desert. ${ }^{33}$ Appearing in a long list of Yahweh's miracles performed during the exodus and wandering, the polysemy underscores the continual renewal and prosperity of the Israelites, despite their constant defiance and transgressions during this time. This is, after all, the central theme of the Psalm.

Psalm 92:11-12

11

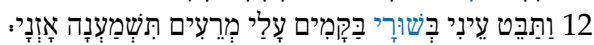

You raise my horn like that of a wild ox. I am soaked in fresh oil.

My eye has seen the defeat of my ambushers, my ears have heard the rout of the wicked.

The reference to the רְאים "wild ox" in line 11 finds an allusive counterpart in line 12 in the odd expression שִּר "my ambushers." In fact, its peculiarity draws our attention. ${ }^{34}$ After just encountering the wild ox one cannot help but hear in the expression the word "bull." Visually this would be even more obvious in the pre-Masoretic text. Enhancing the

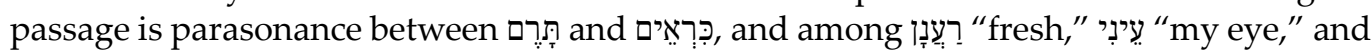
"מִרְִעים "wicked." The psalmist contrasts himself as a wild bull with his enemies who hide in ambush, but who are here paronomastically transformed into domesticated bovids.

Isaiah 30:23-24

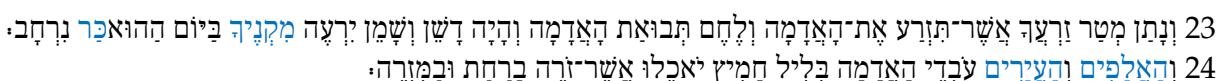

So rain will be provided for the seed with which you sow the ground, and the bread that the ground brings forth will be rich and fat. Your livestock, in that day, will graze in broad pastures.

As for the cattle and the asses that till the soil, they will partake of the salted fodder that has been winnowed with shovel and fan.

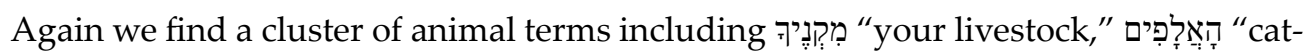

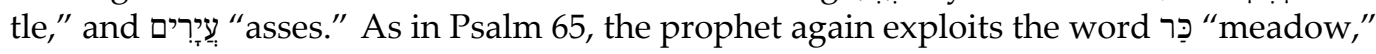
which resounds כָּ "ram." Though כָּ can only mean "meadow" here, the prophecy guarantees the fecundity of Israel's agriculture and herds, and so the allusion to "ram" is fitting.

Jeremiah 49:22-23

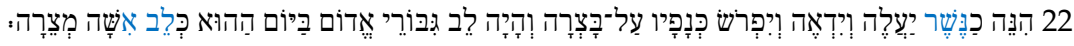

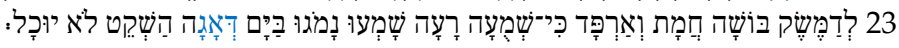


Behold, like a raptor he flies up. He soars and spreads his wings against Bozrah, and the heart of Edom's warriors in that day will be like the heart of a woman in travail.

Concerning Damascus: Hamath and Arpad are ashamed for they have heard the evil news. They quake, anxiety in the sea that cannot rest.

These verses represent both the end of the prophet's harangue against Edom, which starts much earlier (Jer 49:7), and the start of his prophecy against the Aramaean cities. Animal images appear in line 16, in which the cliff dwelling Edomites are likened to the "rov "raptor" that nests in high places. Jeremiah then compares Yahweh's approach to an "lion" that emerges from the jungle of the Jordan (49:19). Among those who will suffer are the young boys of the "flocks" (49:20). It is at this juncture that the highlighted text commences likening Yahweh to a soaring "ְִֶּ "raptor." Embedded amongst the cluster of animal similes is the expression

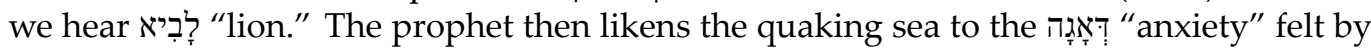

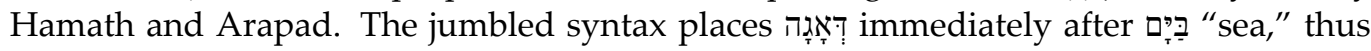
encouraging one to hear in their anxiety the word "Tָ "fish." The device here functions to emphasize the speed (raptor) and power (lion) that will fall upon Edom and the Aramaean cities, who will find themselves unawares and anxiously teeming like fish in a quaking sea.

Ezekiel 34:11-12

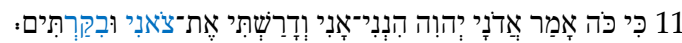

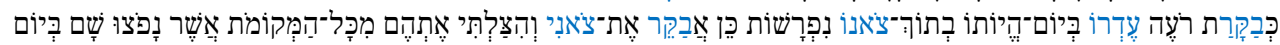

12

For thus says the Lord Yahweh, "Here am I! I am going to search for my flock and I will seek them out.

As a shepherd seeks out his flock when some (animals) in his flock have gotten separated, so I will seek out my flock. I will rescue them from all the places to which they were scattered on a day of cloud and gloom.

Ezekiel's prophecy promises to return the people Israel to their own land. Contribut-

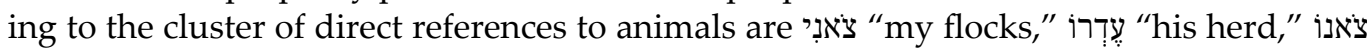
"his flocks," and "צאני "my flocks." The abundant mention of pasture animals finds hidden

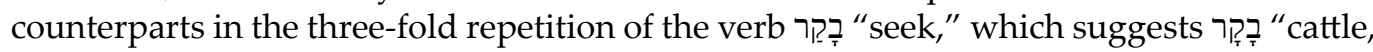

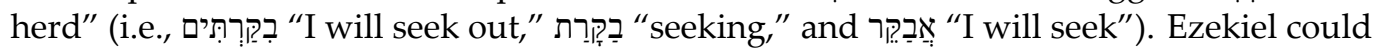

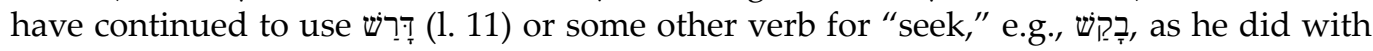

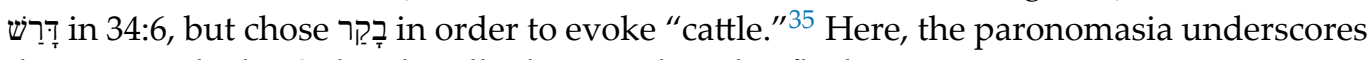
the active role that Yahweh will take in seeking his flock.

Poor Man of Nippur, 93-93

92. NU.BÀN.DA ana šúm-'u-ud ma-ka-li-šú ŠUM-uh UDU.AS 4 .[LUM]

The chief slaughtered a pasil[ $[u]$ sheep to in[cre]ase his meal.

93. KI.MIN ina mah-ri-š́u us-a an-ha-ku-ma qí-b[i]

Likewise, he (the chief), said in his presence: "Alas, am I tired!"

Our final example comes from an Akkadian text known as the Poor Man of Nippur. Baruch Ottervanger observed a particularly clever use of allusive paronomasia in the text's use of the interjection ua "woe, alas" (Ottervanger 2016, p. 36). The scribe has employed the sign $u_{8}$ in the interjection, because it also is a logogram for lahru "sheep," and thus, a fitting follow-up to the pasillu-sheep, which the poem mentions in the preceding line.

\section{Conclusions}

The evidence gathered here demonstrates that there is a high propensity for finding creatures hidden in biblical texts that cluster or feature direct references to animals. This is especially the case in Proverbs, which places great emphasis on the observation of wild 
animals to obtain divine wisdom and instructs would-be learners to search for hidden wisdom in the proverbs' figures and riddles. However, we also find the device in a number of psalms and prophecies, not all of which one can classify as "wisdom texts." ${ }^{36}$ The exemplar from the Akkadian Poor Man of Nippur also reveals that the device predated Israel. ${ }^{37}$

One of the most salient differences of the animals hidden in texts other than Proverbs is that most of them are domesticated. Only in Jer 49:22-23 do we find wild animals, and if one accepts the reference to the Phoenix in Ps 78:27, we have a mythological creature. ${ }^{38}$ The latter is especially interesting as it is our only case involving polysemy as well. All others are alluded by means of paronomasia. This suggests that the motives informing the concealment of animals in Proverbs are not the same as those behind the device in other books. Certainly, Ps 22:17 outwardly bears a resemblance to Proverbs in that it hides the word "lions" within the word "dogs." Yet, there is little that appears numinous here, as both animals describe the psalmist's enemies. It would appear then, that the device merely aims to force one to see the dogs as lions in retrospect, as greater threats than they once appeared. The passage in Jer 49:22-23 also resembles Proverbs in that it depicts Yahweh as a raptor and embeds a lion into the text, both in keeping with the numinous understanding of wild animals. However, the text is a prophecy that describes the downfall of city-states as a sudden and surprise attack. Therefore, the raptor and hidden lion appear to emphasize these aspects of Yahweh's actions. The hidden Phoenix in Ps 78:27 also functions differently. It emphasizes the central theme of the poem that Yahweh continually renewed Israel, even in the face of their nearly constant defiance during the exodus and wandering.

All the cases involving domesticated animals similarly appear to be rhetorical, or perhaps performative, in function. Three of them (Ps 49:13, 49:15, Ezek 34:11-12) embed the word בָזָר "cattle, herd," but in different ways, and two others (Ps 65:14, Isa 30:23-24) employ the polyseme was more frequent in common parlance. ${ }^{39}$ The passage in Isaiah occurs in a prophecy that promises the fertility of Israel's crops and animals. Therefore, it cleverly combines the two. Our final two examples (Ps 50:9-11, 92:11-12) embed allusions to "cattle" and a שוֹ "bull," respectively. The former occurs in a passage placed in Yahweh's voice that literally forces one to distinguish the domesticated animals of sacrifice from "every animal of the forest, the beasts on a thousand mountains," which belong to him. The paronomastic allusion in Psalm 92 also functions to contrast the psalmist as wild bull, with his now defeated (domesticated) ambushers.

This study has presented numerous examples of a hitherto-unrecognized device that involves paronomastically embedding the names of animals in texts that feature and/or cluster direct references to animals. Its use in Proverbs is distinctive and relates to the notion that one can derive divine wisdom from wild animals and their behavior. Its use elsewhere is rhetorical, and perhaps even performative. By way of conclusion, we feel it important to emphasize again that our finds add to a growing list of textual devices that exploit or employ clusters. Therefore, we aver that there is great propriety in looking for paronomasia on objects hidden in texts that feature a particular theme or cluster of connected objects, even those beyond the animal kingdom. Nevertheless, it is likely that if researchers are attentive to a text's use of wildlife imagery, they will find many more lions between the lines.

Author Contributions: All authors have equal contributions to the paper, and read and agreed to the published version of the manuscript.

Funding: This research received no external funding.

Conflicts of Interest: The authors declare no conflict of interest.

\section{Notes}

On the allusive and concealing functions of paronomasia, see (Noegel 2021, pp. 91-97, 130-33). 
On paronomasia generally in Proverbs, see (Weiser 1959; Støry 1993; McCreesh 1991; Rendsburg 1997; Hurowitz 1999; Keefer 2017; Kselman 2002).

3 See, e.g., acrostics, polysemy clusters, body part clusters, and geminate clusters in (Noegel 2021, pp. 195-207, 218-29, 286-95, 310-11).

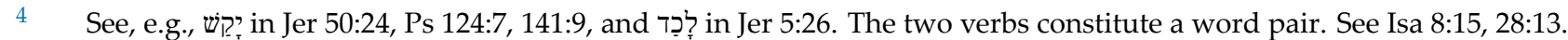

5 For a useful treatment on the use of hunting and trapping terms in the Bible, see (Forti 2008, pp. 84-86).

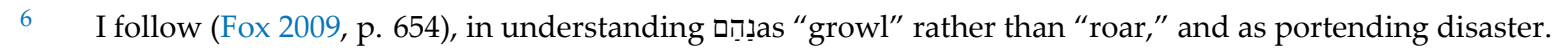

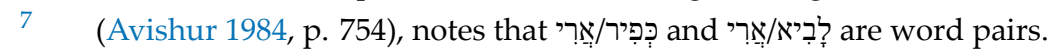

8 (Keefer 2017, p. 47), notes of rare words, “in most cases, the term's meaning does not justify its presence in the text; more common terms are expected. The rare words, however, contribute to discernable phonic schemes of consonants and vowels in the MT."

9 The word הַוֹ conveys both destruction from natural or divine causes (e.g., Ps 91:3) and harmful speech (e.g., Job 6:30), as noted by (Hurowitz 2012, p. 400).

10 The word עָצָcan mean "counsel," but also "rebellion, revolt, disobedience" (cf. Ps 13:3, 106:43). The notion of rebellion also

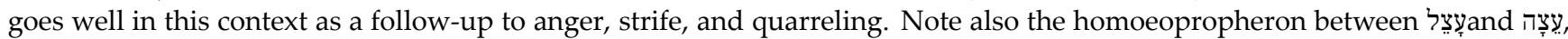
and between יָחרֶש

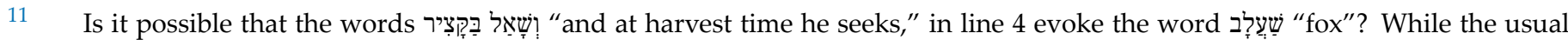

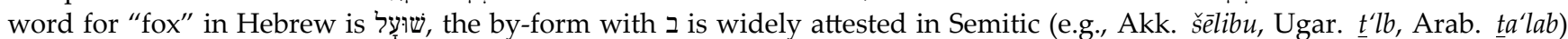

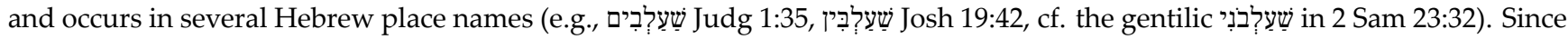
foxes typically inhabit ruins and other desolate places in the Bible (e.g., Ezek 13:4, Lam 5:18), the allusion to this animal would underscore the bareness of the lazy man's harvest.

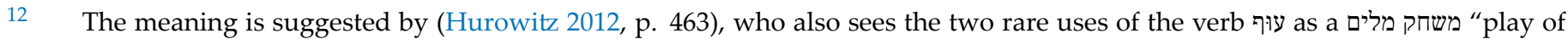

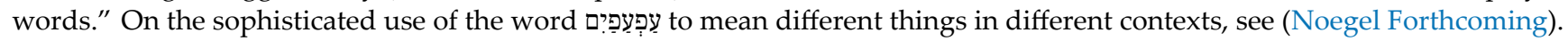

13 (Lewis 1996, pp. 40-41), discusses the juxtaposition of lions and serpents in iconography and in the Hebrew Bible, including Ps 91:13, Isa 30:6, and Amos 5:19, along with Ezek 32:2.

14 We note also the homoeopropheron between

15 Elsewhere biblical authors exploited the polysemous root $ם$ רח to mean "rain" as well. See (Rendsburg 1983).

16 On amphiboly, see (Noegel 2021, pp. 233-39).

17 On additional devices operative in these crafty proverbs, see (Noegel and Nichols 2019).

18 See (Hurowitz 2012, p. 569), who suggests the parallel to Joel 1:6: a nation has come up upon my land, vast beyond counting, with the teeth of a lion, and molars of a lion"; also Ps 58:7, Job 29:16-17.

19 We note additional anagrammatic paronomasia between עִינָ "my eyes" (30:13) and "poor" (30:14).

20 On the numinous nature of wild animals and their relationship to God and humankind in the Hebrew Bible, see (Noegel 2019, pp. 95-133). Evidence also suggests that animals existed in a close enough relationship to humankind to praise God. See (Strawn and LeMon 2007, pp. 451-85; Atkins 2020, pp. 500-13).

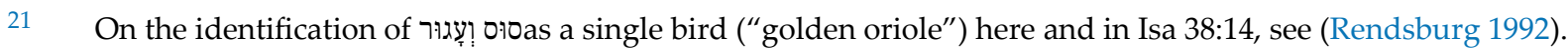

22 The rhetorical queries constitute a corrective retort to Job's previous statement: "Wisdom, whence does it come, and where is the place of understanding? It is hidden from the eyes of every living being, and concealed even from the birds of the sky" (Job 28:20-21). (Pope 1973, pp. 290, 302), renders “Who put wisdom in Thoth? Who gave Sekwi understanding?" He takes Sekwi to reflect an Egyptian word for the planet Mercury.

23 Nevertheless, as (Strawn 2005, p. 55) also notes, “. . . there are surprisingly few references to Israelite monarchs as lions.” Italics are his.

24 For a comprehensive treatment concerning the taxonomy of animals in the Hebrew Bible, see (Noegel 2019, pp. 95-133). With regard to the horse embedded in Prov 23:32, there is no reason to assume a horse is domesticated unless it is explicitly described as such. Since horses continued to exist in the wild and resisted domestication, it is likely that the Israelites viewed them as partially wild. Compare, for example, the comparison of horses to wild animals in Hab 1:8.

25 Acrostics too are a form of cluster. See (Noegel 2021, pp. 225-26, 269).

26 On animal imagery in the Psalms, see (Forti 2018).

27 (Dahood 1966, p. 141), does not read כָּאָרִ as "like a lion," but as "piercing," as if derived from the root

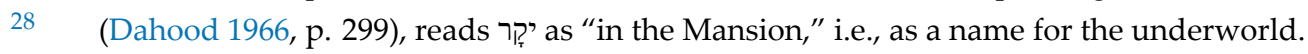

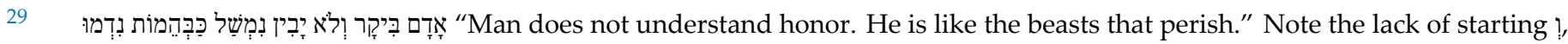

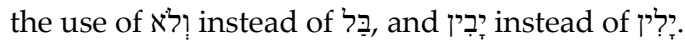

30 (Dahood 1966, p. 300), proposes that we emend the text to read "into his gullet like a calf." We do not suggest that the text requires emendation, but that it successfully alludes to the animal as is. 


\section{References}

Atkins, Peter Joshua. 2020. Praise by Animals in the Hebrew Bible. Journal for the Study of the Old Testament 44: 500-13. [CrossRef] Avishur, Yitzhak. 1984. Stylistic Studies of Word-Pairs in Biblical and Ancient Semitic Literatures. AOAT 210. Kevelaer: Butzon \& Bercker. Dahood, Mitchell. 1966. Psalms I: 1-50. Garden City: Doubleday.

Dahood, Mitchell. 1974. Hộl "Phoenix" in Job 29:18 and in Ugaritic. Catholic Biblical Quarterly 36: 85-88.

Forti, Tova L. 2008. Animal Imagery in the Book of Proverbs. VTSup 118. Leiden: Brill.

Forti, Tova L. 2015. Gattung and Sitz im Leben: Methodological Vagueness in Defining Wisdom Psalms. In Was There a Wisdom Tradition? New Prospects in Israelite Wisdom Studies. Edited by Mark R. Sneed. Ancient Israel and Its Literature 23. Atlanta: Society of Biblical Literature, pp. 205-20.

Forti, Tova L. 2018. "Like a Lone Bird on a Roof": Animal Imagery and the Structure of Psalms. Critical Studies in the Hebrew Bible 10. University Park: Eisenbrauns.

Fox, Michael V. 2009. Proverbs 10-31. New Haven and London: Yale University Press.

Greenberg, Moshe. 1997. Ezekiel 21-37. Garden City: Doubleday.

Greenfield, Jonas C. 1990. The "Cluster" in Biblical Poetry. Maarav 55-56: 159-68.

Hossfeld, Frank L., and Erich Zenger. 2005. Psalms, Volume 2 (51-100): Hermeneia, a Critical and Historical Commentary on the Bible. Translated by Linda M. Maloney. Hermeneia Commentary Series; Minneapolis: Fortress Press.

Hurowitz, Victor A. 1999. Nursling, Advisor, Architect אמון

Hurowitz, Victor A. 2012. Proverbs: Introduction and Commentary. 2 vols. Jerusalem: Magnes Press. (In Hebrew)

Keefer, Arthur. 2017. Sound Patterns as Motivation for Rare Words in Proverbs 1-9. Journal of Northwest Semitic Languages 43: 35-49.

Keel, Othmar, and Silvia Schroer. 2015. Creation: Biblical Theologies in the Context of the Ancient Near East. Translated by Peter T. Daniels. Winona Lake: Eisenbrauns.

Kselman, John S. 2002. Ambiguity and Wordplay in Proverbs XI. Vetus Testamentum 52: 545-47. [CrossRef]

Lewis, Theodore J. 1996. CT 13.33-34 and Ezekiel 32: Lion-Dragon Myths. Journal of the American Oriental Society 116: 28-47. [CrossRef]

McCreesh, Thomas P. 1991. Biblical Sound and Sense: Poetic Sound Patterns in Proverbs 10-29. JSOTSup 128. Sheffield: Sheffield Academic.

Noegel, Scott B. 2019. From Ape to Zebra: On Wild Animals and Taxonomy in Ancient Israel. In Animals and Their Relation to Gods, Humans and Things in the Ancient World. Edited by Raija Mattila, Sanae Ito and Sebastian Fink. Studies in Universal and Cultural History. Wiesbaden: Springer, pp. 95-133.

Noegel, Scott B. 2020. When Animals Speak. Journal of the Ancient near East Society 34: 107-35.

Noegel, Scott B. 2021. "Word Play" in Ancient Near Eastern Texts. ANEMS 26. Atlanta: Society of Biblical Literature Press.

Noegel, Scott B. Forthcoming. Eyelids of the Dawn.

Noegel, Scott B., and Corinna E. Nichols. 2019. Seeing Doubles: On Two of a Kind. Journal for the Study of the Old Testament 45: 1-12. [CrossRef]

Ottervanger, Baruch. 2016. The Tale of the Poor Man of Nippur. SAACT 12. Helsinki: Neo-Assyrian Text Corpus Project.

Pope, Marvin H. 1973. Job. Garden City: Doubleday.

Rendsburg, Gary A. 1983. Hebrew RHM = "Rain". Vetus Testamentum 3: 357-62. 
Rendsburg, Gary A. 1992. Eblaite sa-su-ga-lum = Hebrew ssgr. In Eblaitica: Essays on the Ebla Archives and Eblaite Language. Edited by Cyrus H. Gordon and Gary A. Rendsburg. Winona Lake: Eisenbrauns, vol. 3, pp. 151-53.

Rendsburg, Gary A. 1997. Double Polysemy in Proverbs 31:19. In Humanism, Culture, and Language in the Near East: Studies in Honor of Georg Krotkoff. Edited by Asma Afsaruddin and A. H. Mathias Zahniser. Winona Lake: Eisenbrauns, pp. 267-74.

Riede, Peter. 2002. Im Spiegel der Tiere: Studien zum Verhaltnis von Mensch und Tier im alten Israel. OBO 187. Göttingen: Vandenhoeck \& Ruprecht.

Støry, Solfrid. 1993. On Proverbs and Riddles: Polar Word Pairs and Other Poetic Devices, and the Words for "Poor and Needy" in the Book of Proverbs. Scandinavian Journal of the Old Testament 7: 270-84. [CrossRef]

Strawn, Brent A. 2005. What Is Stronger than a Lion?: Leonine Image and Metaphor in the Hebrew Bible and the Ancient Near East. OBO 212. Göttingen: Vandenhoeck \& Ruprecht.

Strawn, Brent A., and Joel M. LeMon. 2007. "Everything That Has Breath": Animal Praise in Psalm 150:6 in the Light of Ancient Near Eastern Iconography. In Bilder als Quellen/Images as Sources: Studies on Ancient Near Eastern Artefacts and the Bible Inspired by the Work of Othmar Keel. Edited by Susanne Bickel, Silvia Schroe, René Schurte and Christoph Uehlinger. Fribourg: Academic Press, pp. 451-85.

Weiser, Asher. 1959. Wordplay in the Book of Proverbs. Publications of the Israel Biblical Research Society 7: 140-47. (In Hebrew) 